\title{
The System-Oriented Perspectives of Inculcating Innovative Technologies for Social Work
}

\author{
Savelchuk Irina \\ ORCID ID: http://orcid.org/0000-0001-6813-4548 \\ Ph.D., Associate Professor \\ Dragomanov National Pedagogical University
}

\begin{abstract}
This article is devoted to the study of system-oriented perspectives of modern social work as a scientific and theoretical basis for the introduction of innovative methods and technologies into the practice of providing social services to different categories of clients. It was determined that the systematic orientation of social work is a key resource that provides a coherent picture of the client's world, about the possibilities and the result of the systematic interaction of social workers with a client and his/her close surrounded, with a group of clients and a community.

Special attention is focused on the peculiarities of the introduction of innovative methods and technologies for social work. The perspective of the ideas of the system methodology during the development and implementation of innovations, the success of which is determined by the system integrity, is emphasized, which greatly enhances opportunities and prospects of social work with certain groups of clients. technologies.

Key words: social work, integration of theory and practice, innovative methods, innovative
\end{abstract}

Актуальність. Об’єктивна соціальна значущість соціальної роботи як практичної діяльності переконливо доводить необхідність пошуку та виявлення соціально-орієнтованих перспектив, які дозволяють побудувати ефективний механізм надання соціальних послуг клієнтам з урахуванням взаємозв'язку теорії та практики.

Системний підхід як напрям наукової методології представлено досить поширено у соціально-педагогічних дослідженнях та дослідженнях в галузі соціальної роботи (О.В. Безпалько, О.Л. Караман, О.Г. Карпенко, В.А. Поліщук, Т.В. Семігіна, I.I. Мигович, Benyamin Chetkov-Yanoov, Malcolm Payne, Hutchinson Gunn Strand, Oltedal Siv та ін.). Зокрема, розкривається специфіка організації на засадах системного підходу соціально-педагогічної роботи 3 дітьми та учнівською молоддю в територіальній громаді [1], соціально-педагогічної роботи з неповнолітніми засудженими [2], соціальної роботи з людьми похилого віку [4], що зумовлено можливостями інтеграції теорії й практики щодо впровадження інновацій. 
Водночас, назріла нагальна потреба у застосуванні системно-орієнтованих перспектив, які б визначали «нову» філософію та методологію вирішення соціальних проблем. У контексті обгрунтування принципових положень системно-орієнтованої практики соціальної роботи повинно відбуватися актуалізація чинників, які б, з одного боку, забезпечували дієвість системної методології для досліджень в галузі соціальної роботи, а з іншого, сприяли ефективному застосуванню системної моделі щодо впровадження інновацій до практичної соціальної роботи з різними категоріями соціально незахищеного населення.

Виклад основного матеріалу. Опанування професію «соціальний працівник» потребує послідовного і грунтовного врахування своєрідності та ідентичності соціальної роботи, закономірностей iї функціонування та розвитку, структурованої спрямованості напрямів як певної цілісності соціальної роботи. Об'єктивно забезпечити найбільш повне використання потенціалу соціальної роботи, неможливо також і без правильного використання ідеї системної організації соціальної роботи. Системне орієнтування соціальної роботи може виступити тим ключовим ресурсом, що забезпечує цілісне уявлення про світ клієнта, про можливості та результат системної взаємодії соціальних працівників з клієнтом і його оточенням, групою клієнтів, громадою тощо.

Водночас слід зазначити, що теорія і практика соціальної робота є самостійними елементами цілісної системи соціальної роботи і без розуміння специфічних закономірностей, які характерні їм як єдиній системі, не можна зрозуміти і мати цілісне уявлення про соціальну роботу як суспільне явище, ii інституалізацію й професіоналізацію. Саме тому, питання наукового обгрунтування предмету, об'єкту та методів соціальної роботи, їі змісту й структури на засадах системного підходу [3] сприяють не тільки розвитку методології соціальної роботи, а й розкривають інтегративний характер системному підходу стосовно впровадження інновацій в практику соціальної роботи $[7 ; 8 ; 12 ; 13]$.

Труднощі, які зустрічаються в процесі розробки, впровадження та поширенні інновацій до сфери надання соціальних послуг, певною мірою, відображають обмеженість вибору теорії цілями практичної діяльності. Натомість відображати співвідношення різних теорій щодо кожного конкретних соціальних випадків у роботі 3 
клієнтами, групою клієнтів, громадою стане можливим, якщо застосовувати критерії значущості теорії для практики соціальної роботи [13, с. 227]: сфера застосування, викладання (вивчення), успішності та доцільність застосування. Виходячи з означених критеріїв, переваги визначення теорій (системна, психодинамічна, научіння, інтеракціоніська, конфліктів [13]) полягають у тому, що кожна з теорій, по-перше, визначає та пояснює практичну діяльність, а по-друге, є мобільною та гнучкою щодо змін пріоритетних проблем практики соціальної роботи. Таким чином, теорії спираючись на практичний досвід соціальної роботи відповідають соціальним проблемам сьогодення та майбутнього.

Водночас, у сучасних умовах співвідношення чинників становлення та розвитку теорії та практики, що спричинено історичними та соціально-економічними особливостями визначаються практичні моделі соціальної роботи [12]: клінічна соціальна робота, соціальна допомога або соціальне забезпечення, соціальна педагогіка як форма соціальної роботи, соціальний розвиток. Об'єднуючим чинником цих моделей може виступити системна методологія дослідження, оскільки «професійне мислення фахівців соціального сфери, освіта в галузі соціальної роботи відображає дослідження складного характеру тієї чи іншої соціальної роботи в Європі, і в інших країнах світу» [12].

Ідея системної методології об’єднує теорії через усвідомлення загального та особливого в концепціях, які обгрунтовують різні види соціальної роботи. Перспективи системних ідей в теорії та практичній соціальній роботі полягають у можливості «створення ефективної роботи мережі соціальних послуг, врахування наслідків системно-орієнтованих концепцій соціальної роботи для окремої людини як системи управління змінами і конфліктами завдяки розробки ефективних стратегій існуючих моделей практики» [11]. Отже, у межах системного підходу повинен відбуватися розвиток інноваційних методів і технологій соціальної роботи з різними групами клієнтів та їх впровадження в практику соціальної роботи.

3 позицій системно-орієнтованих перспектив впровадження інноваційних методів та технологій надають подальшому розвитку теорії та практики соціальної роботи. Так, за переконанням М. Пейна [10, с. 165], якщо соціальна робота спрямована на відтворення соціальних контактів й відносин клієнтів, то орієнтується на досягнення 
соціально-значущих цілей (соціальна справедливість, соціальні зміни) поряд 3 розв'язанням міжособистісних проблем. На практиці реалізація таких перспектив здійснюється на засадах медичної (клінічної) роботи, мультидисциплінарних команд фахівців, що працюють з сім'ями та у мікросоціальному середовищі [10, с. 165], через створення соціальної мережі й систем соціальної підтримки [10, с. 188].

Зрозуміло, що соціальна робота на ідеях системного підходу, повинна характеризуватися цілісним характером соціальних змін в умовах надання комплексу соціальних послуг на рівнях, як індивідуальної та групової роботи, так роботі в громаді. При цьому, ми вважаємо, що важливою особливістю може виступити інтеграція теорії та практики соціальної роботи [9] завдяки науково-теоретичним засадам, механізмам реалізації (технологічним, організаційно-методичним), сукупності умов та чинників, що в цілому й забезпечують ефективність й успішність соціальної роботи. У результаті цього, співвідношення, інтегрування або розмежування теорії та практики соціальної роботи стають змістовною методологічною проблемою.

Висновки. Системна методологія соціальної роботи як сукупність принципів, ознак і засобів організації соціальної роботи на індивідуально-особистісному, груповому рівнях, а також на рівні громади забезпечує комплексне вивчення соціального явища або проблеми, впливу різних чинників на їі організацію. Оскільки системна орієнтація теорії соціальної роботи виступає інтеграційним засобом поєднання теорії та практики, то впровадження інновацій соціальної роботи потребує теоретичного обгрунтування вибору інноваційних форм, методів та технологій. Таким чином, враховуючи переваги та обмеження застосування системного підходу в соціальній роботі як методології соціальної роботи, так і практичної соціальної роботи перспективними напрямами подальших наукових пошуків стають розкриття методичних можливостей його застосування у розробці та впровадженні інноваційних методів та технологій у практику надання соціальних послуг різним категоріям клієнтів.

\section{References}

1. Bezpalko O.V. Systemnyy pidkhid do orhanizatsiyi sotsialno-pedahohichnoyi roboty z ditmy ta uchnivs'koyu moloddyu v terytorialniy hromadi [System approach to the organization of socio-pedagogical work with children and students in the territorial community]. Sotsial'na pedahohika: teoriya i praktyka. 2006. No. 3. P. 46-53

2. Karaman O.L. Systemnyy pidkhid yak metodolohiya doslidzhennya sotsial'no- 
pedahohichnoyi roboty $z$ nepovnolitnimy zasudzhenymy $v$ Ukrayini [System approach as a methodology for research on social work with juvenile convicts in Ukraine]. Naukovi zapysky KDPU. Seriya: Pedahohichni nauky / red. kol.: V.V. Radul [ta in.]. Kirovohrad: KDPU. Isuue 107. Part 1. 2012. P. 222-229.

3. Karpenko O.H. Ob'yekt, predmet ta metody sotsial'noyi roboty: systemnyy pidkhid [Object, subject and methods of social work: a systematic approach. Naukovyy chasopys NPU imeni M.P.Drahomanova. Seriya 11. Sotsiolohiya. Sotsial'na robota. Sotsial'na pedahohika. Upravlinnya: Zb. naukovykh prats'. Kyiv: NPU im. M.P.Drahomanova, 2005. Issue 3. P. 99-107.

4. Petko, L. V. Vyklyky XX stolittia dlia osvitnoho prostoru Ukrainy [The challenges of educational space in the 21 - $^{\text {st }}$ century]. Naukovi pratsi Seriia : Pedahohika : nauk. zhurn. Mykolaiv : Vyd-vo ChNU imeni Petra Mohyly, 2017. Vol. 303. Issue. 291. Pp. 10-14.

5. Petko L.V. Stymuliuvannia hotovnosti maibutnikh sotsialnykh pedahohiv do vykhovnoi roboty $u$ protsesi vyvchennia inozemnoi movy u VNZ (na prykladi kinofilmu «Zvuky muzyky» («The Sound of Music»), SShA, rezh. Uaiz, 1965 r.). [Stimulation of readiness of the future social teachers in a higher education institution for educational work in the process of foreign language learning (on the example of the movie «The Sound of Music», USA, Director R. Wise, 1965)]. Aktualni problemy navchannia ta vykhovannia liudei $v$ intehrovanomu seredovyshchi: zb. nauk. prats No 9 (11). Kyiv: Universytet «Ukraina». 2012. Pp. 84-95. URI http://enpuir.npu.edu.ua/handle/123456789/7446

6. Savelchuk I.B. Innovacijni metody socialnoyi roboty $z$ lyudmy poxylogo viku: specyfyka ta osoblyvosti vprovadzhennya [Innovative methods of social work with the elderly: specificity features and implementation]. Molodyj vchenyj. 2015. No 2 (17). P. 95-98.

7. Savelchuk I.B. Naukovo-metodolohichni pidkhody do vprovadzhennya innovatsiy $v$ praktyku sotsial'noyi roboty [Scientific and methodological approaches to the introduction of innovations into the practice of social work]. Sotsialna robota v Ukrayini: teoriya i praktyka: nauk.-metod. zhurnal. Kyiv, 2012. No. 2. P. 180-186.

8. Savelhuk I.B. Metodologichni oriyentyry suchasnoyi social'noyi roboty [Methodological benchmarks for modern social work]. Social `na robota v Ukrayini: teoriya ta prakty `ka. 2016. No. 1-2. P. 36-44.

9. Savelchuk I.B. Do pytannya aktual'nosti problem vzayemozvyazku teoriyi ta praktyky sotsial'noyi roboty [On the issue of relevance of the problems in relationship between theory and practice of social work.]. Naukovyy chasopys NPU imeni M.P. Drahomanova: Seriya 11 "Sotsiolohiya. Sotsialna robota. Sotsialna pedahohika. Upravlinnya". 2011. No. 12. P. 10-15.

10. Peyn M. Sotsyal'naya rabota: sovremennaya teoryya [Social work: modern theory]. Moskva: Akademyya, 2007. 391 p.

11. Chetkov-Yanoov Benyamin. Social Work practice a systems approach. URI: http://www.general-ebooks.com/book/76237092-social-work-practice-a-systems-approachsecond-edition

12. Payne M. European social works and their identities. ERIS: Web Journal. Vol. 5, Issue 2. 2014. P. 1-14. URI: http://periodika.osu.cz/eris

13. Hutchinson Gunn Strand, Oltedal Siv. Five Theories in Social Work. Oslo: 
Universitetsforlaget. UiN-report 1/2014. 260 p.

URI: https://brage.bibsys.no/xmlui//bitstream/id/96588/Hutchinson_GS.pdf

Translation of the Title, Abstract and References to the Author's Language

\section{УДК 364(37:36)}

Савельчук І.Б. Системно-оріснтовані перспективи впровадження інноваційних технологій соціальної роботи.

Ця стаття присвячена дослідженню системно-орієнтованих перспектив сучасної соціальної роботи як науково-теоретичного підгрунтя для впровадження інноваційних методів й технологій до практики надання соціальних послуг різним категоріям клієнтів. Було визначено, що системне орієнтування соціальної роботи виступає тим ключовим ресурсом, який забезпечує цілісне уявлення про світ клієнта, про можливості та результат системної взаємодії соціальних працівників 3 клієнтом і його близьким оточенням, групою клієнтів, громадою. Особлива увага сконцентрована на особливостях впровадження інноваційних методів й технологій соціальної роботи. Наголошено на перспективності ідей системної методології при розробці та впровадженні інновацій, успішність яких визначається системною цілісністю, а це значно розширює можливості та перспективи соціальної роботи з певними групами клієнтів.

Ключові слова: Системна соціальна робота, інтеграція теорії та практики соціальної роботи, інноваційні методи технології соціальної роботи.

Савельчук И.Б. Системно-ориентированные перспективы внедрения инновационных технологий социальной работы.

Эта статья посвящена исследованию системно-ориентированных перспектив современной социальной работы как научно-теоретического основания для внедрения инновационных методов и технологий в практику предоставления социальных услуг различным категориям клиентов. Было определено, что системное ориентирование социальной работы выступает тем ключевым ресурсом, который обеспечивает целостное представление о мире клиента, о возможностях и результате системного взаимодействия социальных работников с клиентом и его близким окружением, группой клиентов, обществом. Особое внимание сконцентрировано на особенностях внедрения инновационных методов и технологий социальной работы. Отмечено перспективность идей системной методологии при разработке и внедрении инноваций, успешность которых определяется системной целостностью, а это значительно расширяет возможности и перспективы социальной работы с определенными группами клиентов.

Ключевые слова. Системная социальная работа, интеграция теории и практики, инновационные методы и технологии социальной работы.

\section{Лimepamypa}

1. Безпалько О. В. Системний підхід до організації соціально-педагогічної роботи 3 дітьми та учнівською молоддю в територіальній громаді. Соціальна педагогіка: теорія і практика. 2006. № 3. С. 46-53. 
2. Караман О.Л. Системний підхід як методологія дослідження соціальнопедагогічної роботи з неповнолітніми засудженими в Україні. Наукові записки КДПУ. Серія: Педагогічні науки / ред. кол.: В. В. Радул [та ін.]. Кіровоград: КДПУ. 2012. Вип. 107. Ч. 1. C . 222-229.

3. Карпенко О.Г. Об'єкт, предмет та методи соціальної роботи: системний підхід. Науковий часопис НПУ імені М.П.Драгоманова. Серія 11. Соціологія. Соціальна робота. Соціальна педагогіка. Управління: зб. наук. пр. Київ: НПУ ім. М.П. Драгоманова, 2005. Вип. 3. С. 99-107.

4. Петько, Л. В. Виклики ХХІ століття для освітнього простору України. Наукові nраці [Чорноморського державного університету імені Петра Могили комплексу "Києво-Могилянська академія"]. Серія : Педагогіка : наук. журн. / Чорном. держ. ун-т імені Петра Могили; ред. кол. : О. П. Мещанінов (голова) [та ін.]. Миколаїв : Вид-во ЧНУ імені Петра Могили, 2017. Т. 303. Вип. 291. С. 10-14.

5. Петько Л.В. Стимулювання готовності майбутніх соціальних педагогів до виховної роботи у процесі вивчення іноземної мови у ВНЗ (на прикладі кінофільму «Звуки музики» («The Sound of Music»), США, реж. Уайз, 1965 р.). Актуальні проблеми навчання та виховання людей в інтегрованому середовищі: зб. наук. праць № 9 (11). Київ: Університет «Україна». $2012 . \quad$ С. $24-95 . \quad$ URI http://enpuir.npu.edu.ua/handle/123456789/7446

6. Савельчук І. Б.. Інноваційні методи соціальної роботи 3 людьми похилого віку: специфика та особливості впровадження. Молодий вчений 2015. № 2 (17). С. 95-98.

7. Савельчук І. Б. Науково-методологічні підходи до впровадження інновацій в практику соціальної роботи. Соціальна робота в Україні: теорія і практика:науковометодичний журнал. 2012. № 2. С. 180-186.

8. Савельчук І.Б. Методологічні орієнтири сучасної соціальної роботи. Соціальна робота в Україні: теорія та практика. 2016. № 1-2. С. 36-44.

9. Савельчук І.Б. До питання актуальності проблем взаємозв'язку теорії та практики соціальної роботи. Науковий часопис НПУ імені М. П. Драгоманова. Серія 11: Соціологія. Соціальна робота. Соціальна педагогіка. Управління. 2011. № 12. С. 10-15.

10. Пейн М. Социальная работа: современная теория: уч. пособие. Москва: Академия, 2007. 391 с.

11. Chetkov-Yanoov Benyamin. Social Work practice a systems approach. URI: http://www.general-ebooks.com/book/76237092-social-work-practice-a-systems-approachsecond-edition

12. Payne M. European social works and their identities. ERIS: Web Journal. 2014. Vol. 5, Issue 2. Pp. 1-14. URI: // http://periodika.osu.cz/eris

13. Hutchinson Gunn Strand, Oltedal Siv. Five Theories in Social Work. Oslo: $\begin{array}{llll}\text { Universitetsforlaget. } & \text { UiN-report } & 1 / 2014 . & \text { c. }\end{array}$ https://brage.bibsys.no/xmlui//bitstream/id/96588/Hutchinson_GS.pdf 